\title{
HIV/AIDS CONTENT KNOWLEDGE AND PRESENTATION STRATEGIES IN BIOLOGY FOR EFFECTIVE USE IN EVERYDAY LIFE
}

\author{
Lindelani Mnguni $^{\#}$ and Mia Abrie \\ Department of Science, Mathematics and Technology Education, University of Pretoria Private bag X20, \\ Hatfield, Pretoria, 0028, South Africa, \\ "lindelani.mnguni@up.ac.za
}

\begin{abstract}
HIV/AIDS education should empower students to create knowledge using everyday life experiences. Such knowledge should then be used to construe experience and resolve social problems such as risk behaviour that leads to infection. In South Africa, attempts to reduce the spread of HIV include incorporating HIV/AIDS education in the Biology curriculum. However, there is a dearth of knowledge regarding the effectiveness of Biology-based HIV/AIDS education. The current study therefore aimed to identify strategies that can be used to enhance Biology students' understanding of HIV/AIDS and promote the use of this knowledge in their daily lives. A predominantly qualitative mixed-method approach with Delphi technique was used to gather and analyse data from secondary-school Biology students and teachers, as well as HIV/AIDS experts specializing in medicine and research. Findings show that most students rely on knowledge learnt in Biology to make decisions related to HIV/AIDS. Respondents suggested that HIV/AIDS education should be taught collaboratively by teachers, people living with HIV, and HIV/AIDS experts. Biology concepts and teaching strategies that could enhance students' understanding of HIV/AIDS, which are not part of the current Biology curriculum, were identified.
\end{abstract}

Keywords: HIV/AIDS; Biology; content knowledge; instructional strategies 


\section{Introduction}

Education has a potential to affect behavioural practices of South African students to prevent HIV infection through acquisition and utilization of scientific knowledge and skills. However, Hodson (2004: 2) argues that "science is often portrayed as the de-personalized and disinterested pursuit of objective truth, independent of the society in which it is practised and untouched by ordinary human emotions, values, and conventions." As a result, content knowledge taught to students as well as teaching strategies used tend to fail to impact students' everyday lives. The research presented in this paper was therefore necessary so that education could "shape the experiences of the young so that instead of reproducing current habits, better habits shall be formed, and thus the future adult society be an improvement on their own" (Dewey, 1916: 79).

\section{Theoretical background}

The area of HIV/AIDS education is an intriguing one, particularly in South Africa where HIV/AIDS remains a serious challenge. Although education-based attempts have been made to promote HIV/AIDS awareness, some scholars argue that these attempts lack effectiveness (Bertrand et al., 2006; Page et al., 2006). Other scholars blame this ineffectiveness on inadequate and scientifically inaccurate HIV/AIDS information being taught in schools (Anderson and Beutel, 2007; Dorrington et al., 2006). There is therefore a need to improve the standard of HIV/AIDS education in schools guided by a lucid HIV/AIDS education framework, and by improvement of content knowledge and the instructional process (Anderson and Beutel, 2007). This improvement should focus mainly on Biology because this is the subject area where scientific knowledge related to HIV/AIDS is taught (Department of Education, 2003). Biology students in South African are taught about the life cycle of HIV, the 
structure of the virus and the immune system in relation to HIV/AIDS (Department of Education, 2003). Knowledge related to promoting abstinence, faithfulness to one sexual partner and condomizing, also known as $\mathrm{ABC}$, is taught in other subjects such as Life Orientation.

In South Africa, behaviour such as promiscuity has been identified as the major factor propelling the spread of HIV (Anderson and Beutel, 2007). There is however a dearth of knowledge on whether Biology is providing students with adequate knowledge to promote safe behaviour. According to the theory of planned behaviour, attitudes, subjective norms and perceived behavioural control are factors that determine behaviour (Ajzen, 1991). These factors are influenced by beliefs, which are determined by knowledge (Ajzen, 1991). Therefore, provision of scientifically correct and contextually relevant knowledge could be used to promote safe behaviour.

Van Manen (1978) and Warde (1960) argue that content knowledge and instructional process should be informed by the social, cultural and personal contexts of those learning instead of the "authorities" (MacDonald, 1971). Furthermore, education should be about learning to live; a phenomenon called citizenship education, rather than knowledge acquisition alone (Warde, 1960; Waghid, 2002). This means content knowledge should be selected and presented in such a way that students can relate their experiences to it. Consequently, there is a need to "humanize" HIV/AIDS education so that "students can graduate alive" (Centre for the Study of AIDS, 2007: 14). 


\section{Objectives and research questions}

Based on the above arguments, the study aimed to identify strategies that can be used to enhance Biology students' understanding of HIV/AIDS and the use of this knowledge in their daily lives. To contextualize this aim, the following research questions were asked:

1. Are the concepts related to HIV/AIDS currently taught in Biology used by students in their decision-making?

2. What can be done to enhance the understanding and use of HIV/AIDS-related concepts for Biology students?

These questions were asked based on the acceptance that the Biology curriculum teaches students various HIV/AIDS-related concepts and skills that foster the ability to "construct and apply knowledge" (Department of Education, 2003). As a result, by understanding these concepts, students may use the knowledge in their lives in the context of HIV/AIDS.

With respect to data collection and analysis towards answering the above research questions, three areas were attended to: i) determining the tendency to apply HIV/AIDS-related knowledge currently taught in Biology to everyday life, ii) identifying HIV/AIDS-related concepts that should be taught in Biology to affect behaviour, and iii) identifying teaching strategies that will best help students understand HIV/AIDS.

\section{Methodology}

A predominantly qualitative mixed-method approach based on a modified Delphi technique was employed for data collection and analysis (Clayton et al., 2006; Hatcher and Colton, 2007). In a Delphi study, a series of rounds are used for data collection. Normally the first 
round is unstructured, which allows respondents to freely identify important issues (Boath et al., 1997). A structured questionnaire is then formulated using data from the first round (Clayton et al., 2006). Respondents answer the questionnaire, and their findings are used to formulate a third-round questionnaire. Once the responses are stable, i.e. they do not produce any new knowledge, the researcher may decide to stop collecting data. The number of rounds of data collection therefore varies from one study to the next (Clayton et al., 2006).

\section{Sampling}

In selecting students and teachers to participate in the study, a non-probability convenience sampling approach was followed. A group of nine schools from Umsunduzi district were selected for participation based on their location and school type. This resulted in the selection of two rural government schools, two urban government schools, three urban private schools and two township government schools. Class size ranged from 25 to 28 , with some schools having more classes for a particular grade than others. Within these schools, a total of 308 grade 11 students aged between 15 and 18 years were enrolled in Biology and participated in the study. Twelve Biology teachers working in these schools also participated in the study. Participating HIV/AIDS experts $(n=19)$ were selected using a non-probability purposive method. The group was comprised of nine medical microbiology researchers working on HIV/AIDS and tuberculosis, and 10 medical practitioners working as pathologists, nursing staff and medical doctors. All participating HIV/AIDS experts were graduates who were familiar with the Biology curriculum but had never participated in Biology curriculum development. Ethical clearance and consent were received from all respondents and relevant stakeholders according to the guidelines of the University of Pretoria. 


\section{Questionnaire design and validation}

To collect data in the first round of the Delphi method, respondents were asked to complete an open-ended questionnaire. Respondents were asked to indicate (in their opinion) using openended responses:

1. whether HIV/AIDS-related concepts currently taught in Biology are used in making decisions related to HIV/AIDS, such as the use of condoms;

2. which concepts related to HIV/AIDS should be taught in school Biology in order for students to adopt safe behavioural practices in the context of HIV/AIDS;

3. which teaching strategies could best help students better understand the concepts related to HIV/AIDS stated in 2.

Questions related to (1) above were only answered by students as they were only applicable to them.

The questionnaire was validated for face and content validity through a separate panel of experts comprised of six science education teachers and an English-language expert (Golafshani, 2003). Through three rounds of assessment, this panel of experts provided their comments and recommendations for the questionnaire, which were then used to revise all of the questions.

\section{Data collection and analysis}

The final questionnaire was then administered for the first round of data collection where responses were analysed following an intercoder format to identify the most prominent themes using inductive coding as described by Thomas (2003). The first step of the analysis was a close reading of the textual responses (Creswell, 2008). The text was read in detail so that the researchers could familiarise themselves with the content. Then the researchers identified 
themes that emerged from the data (Creswell, 2008; Thomas, 2003). These themes were also based on meanings of actual phrases used in specific text segments. At the end of this process, the researchers had generated a list of recommended themes which according to the respondents are critical to enhancing students' understanding of HIV/AIDS and the usability of Biology in everyday life.

Having obtained data from the first round, a second round of data collection was carried out (Clayton et al., 2006; Hatcher and Colton, 2007). For data collection, a questionnaire consisting of closed-ended and open-ended questions was developed and administered (Appendix 1). The closed questions were statements to which the respondents were to indicate whether they strongly agreed, agreed, disagreed or strongly disagreed. Respondents also had to, where necessary, justify their choices. In designing the questionnaire, the researchers used results from the first round. For example, if in the first round it emerged that visuals are necessary to teach about HIV/AIDS, then the questionnaire would include an item probing agreement or disagreement with this view. Only those concepts that were recommended by over $60 \%$ of the respondents in the first round were included in the questionnaire and investigated in the second round of data collection. Respondents however still had an opportunity to include new concepts that were not on the list. The questionnaire was validated in a manner similar to the first questionnaire. Data collected in the second round were then subjected to a mixed method of analysis that involved inductive analysis as well as working out descriptive statistics, such as frequencies and means (Creswell, 2008). No further data were collected as the researcher observed constancy in the findings such that further data would not have a significant impact on them. With reference to findings below, respondents quoted are indicated next to each quote in brackets, "L" indicating a learner, "T", a teacher and "E" an HIV/AIDS expert. 


\section{Findings}

The first-round questionnaire using the modified Delphi method revealed a number of issues regarding the teaching of HIV/AIDS in Biology that were later verified in round two. To avoid unnecessary redundancy, only final findings are presented.

\section{Students' use of HIV/AIDS-related knowledge currently taught in Biology}

To determine whether knowledge taught in Biology is used in everyday life situations, students were asked to indicate how often they use knowledge learnt in Biology about HIV/AIDS to make decisions about their sexual lives (Table 1). A significant number of students (59\%) indicated that they always use HIV/AIDS knowledge learnt in Biology when making decisions related to HIV/AIDS (Table 1). This was true even if they were not sexually active. However, a significantly low $4 \%$ of the students suggested that they do not use Biology knowledge (Table 1). While this figure is low, it is noteworthy in that not all students use HIV/AIDS knowledge taught in Biology in their lives. A number of reasons were provided for this. Qualitative analysis of the data revealed that when "presented as dry facts, which is usually the case, knowledge is not usable" in everyday life (L074). It also emerged that knowledge should be "practical and relevant to the lives of students" (L008) indicated). It was further argued that "many [students] choose not to [use knowledge learnt in Biology] because they do not see [what is learnt at] school as part of everyday life" (L033). Data also revealed that Biology teachers "do not teach students to [use] their knowledge in everyday life" (L301).

Nevertheless, other respondents were positive and argued that "[Biology is] very important. With the right education students are given the tools to approach life and make the right decisions" (E08). Given that some $41 \%$ of the respondents suggest that Biology is, to some 
extent, neither relevant nor usable, the researchers went on to identify potential content knowledge that could be used to improve HIV/AIDS education through Biology.

Table 1. A summary of students' $(n=308)$ responses indicating how often they use biology knowledge in their decision-making related to HIV/AIDS

\begin{tabular}{|l|l|l|l|l|l|}
\hline Response & Always & Frequently & Seldom & Never & No response \\
\hline Proportion & $182(59 \%)$ & $74(29 \%)$ & $28(9 \%)$ & $12(4 \%)$ & $12(4 \%)$ \\
\hline $95 \%$ CI for mean & 48.5 to 75.5 & 60.7 to 63.3 & 58.2 to 65.8 & 56.4 to 67.6 & 56.4 to 67.6 \\
\hline Difference & -120 & -12 & 34 & 50 & 50 \\
\hline Degrees of Freedom & 307 & 307 & 307 & 307 & 307 \\
\hline t-test statistic & 17.550 & 17.550 & 17.550 & 17.550 & 17.550 \\
\hline Significance level & $\mathrm{P}<0.0001$ & $\mathrm{P}<0.0001$ & $\mathrm{P}<0.0001$ & $\mathrm{P}<0.0001$ & $\mathrm{P}<0.0001$ \\
\hline
\end{tabular}

\section{Content knowledge}

Regarding content knowledge related to HIV/AIDS, respondents stated that the concepts currently presented in Biology are not adequate to transform behavioural preferences of students. Through inductive coding of the data, concepts related to HIV/AIDS that need to be taught in Biology in order for students to adopt safe behavioural practices in the context of HIV/AIDS fell within five themes: i) properties of HIV/AIDS, ii) HIV-transmission mechanisms, iii) results of infection, iv) immunity against HIV/AIDS, and v) life skills (Table 2). A total of 18 concepts characterized these themes; some were scientific while some were related to life skills. For example, sex education is more of a life-skills concept while the life cycle of HIV can be better understood in the construction of scientific knowledge.

From Table 2, it appears that the respondents felt that HIV/AIDS education within Biology needs improving. The findings indicate that some respondents believe "general knowledge about HIV' needs to be taught (e.g. L212). However, it appears that other respondents would like to see an in-depth look at the subject instead of a superficial general view. In-depth 
concepts that were recommended include the "life cycle of HIV" (T04) and the development of AIDS from HIV infection (E01).

Table 2. A list of concepts that respondents, i.e. students, teachers and HIV/AIDS experts, felt need to be introduced into the biology curriculum. The recommended concepts were suggested by over $60 \%$ of respondents in the first round of data collection and by the proportion given in column 3 in the second round. Example quotes were taken from both rounds of data collection. * indicates concepts that are not in the current Biology curriculum.

\begin{tabular}{|c|c|c|c|}
\hline Theme & $\begin{array}{l}\text { Recommended } \\
\text { concepts }\end{array}$ & $\begin{array}{l}\text { Frequency } \\
(\%)\end{array}$ & Example quote \\
\hline \multirow[t]{3}{*}{$\begin{array}{l}\text { Properties } \\
\text { of } \\
\text { HIV/AIDS }\end{array}$} & $\begin{array}{l}\text { General } \\
\text { knowledge about } \\
\text { HIV }\end{array}$ & 94 & $\begin{array}{l}\text { Teach us general knowledge about HIV } \\
\text { (L212) } \\
\text { Teach more and more about HIV 'cause in } \\
\text { our school I don't even remember when last } \\
\text { they taught us about it (L219) }\end{array}$ \\
\hline & $\begin{array}{l}\text { Multiple } \\
\text { infections* }\end{array}$ & 72 & $\begin{array}{l}\text { The real danger of multiple partners and } \\
\text { multiple infections (E05) }\end{array}$ \\
\hline & Life cycle of HIV & 72 & $\begin{array}{l}\text { They must be taught the life cycle of HIV } \\
\text { (T04) }\end{array}$ \\
\hline \multirow[t]{2}{*}{$\begin{array}{l}\text { HIV modes } \\
\text { of } \\
\text { transmission }\end{array}$} & $\begin{array}{l}\text { Mother-to-child } \\
\text { transmission* }\end{array}$ & 89 & $\begin{array}{l}\text { Mode of transmission, prevention of } \\
\text { infection, mother-to-child transmission and } \\
\text { other STDs (E07) }\end{array}$ \\
\hline & $\begin{array}{l}\text { How to use } \\
\text { condoms and } \\
\text { other prevention } \\
\text { strategies* }\end{array}$ & 67 & $\begin{array}{l}\text { Why and how to use condoms as a method of } \\
\text { preventing sexually transmitted diseases } \\
\text { (E07) }\end{array}$ \\
\hline \multirow[t]{5}{*}{$\begin{array}{l}\text { Results of } \\
\text { infection }\end{array}$} & Effects of AIDS & 89 & $\begin{array}{l}\text { More emphasis on what AIDS does to you } \\
\text { (E03) }\end{array}$ \\
\hline & Symptoms & 83 & They must know the symptoms (T03) \\
\hline & $\begin{array}{l}\text { Progression from } \\
\text { HIV infection to } \\
\text { AIDS* }\end{array}$ & 89 & Teach them how HIV gives AIDS (E01) \\
\hline & $\begin{array}{l}\text { Opportunistic } \\
\text { infections* }\end{array}$ & 89 & $\begin{array}{l}\text { Opportunistic infections that an HIV-positive } \\
\text { patient can get and the effects of each } \\
\text { infection (E05) }\end{array}$ \\
\hline & $\begin{array}{l}\text { Risk of } \\
\text { contracting } \\
\text { sexually } \\
\text { transmitted } \\
\text { infections (STIs)* }\end{array}$ & 56 & $\begin{array}{l}\text { About different types of STIs and how you } \\
\text { can get an STI especially if you have HIV } \\
\text { (L300) }\end{array}$ \\
\hline $\begin{array}{l}\text { Immunity } \\
\text { against } \\
\text { HIV/AIDS }\end{array}$ & $\begin{array}{l}\text { Curability of } \\
\text { HIV/AIDS }\end{array}$ & 89 & $\begin{array}{l}\text { Teach them about the lack of antiretrovirals } \\
\text { available to the public and poor-health } \\
\text { facilities (E05) }\end{array}$ \\
\hline
\end{tabular}




\begin{tabular}{|c|c|c|c|}
\hline & $\begin{array}{l}\text { Protection } \\
\text { strategies and } \\
\text { immunity* }\end{array}$ & 67 & $\begin{array}{l}\text { Emphasis that they should protect } \\
\text { themselves by taking necessary precautions } \\
\text { (E06) }\end{array}$ \\
\hline & Treatment* & 67 & $\begin{array}{l}\text { We should be taught what to do when you } \\
\text { have HIV (L212) }\end{array}$ \\
\hline \multirow[t]{5}{*}{ Life skills } & $\begin{array}{l}\text { How to support } \\
\text { people living with } \\
\text { HIV (and self)* }\end{array}$ & 67 & $\begin{array}{l}\text { How to support people with HIV/AIDS } \\
\text { (L223) }\end{array}$ \\
\hline & Sex education* & 56 & $\begin{array}{l}\text { They must teach students about sexual } \\
\text { intercourse (L228) }\end{array}$ \\
\hline & Testing* & 67 & $\begin{array}{l}\text { The importance of having an HIV test before } \\
\text { having sex (E03) }\end{array}$ \\
\hline & $\begin{array}{l}\text { Decision- } \\
\text { making* }\end{array}$ & 83 & To make informed decisions/choices (L010) \\
\hline & $\begin{array}{l}\text { Responsible } \\
\text { behaviour }\end{array}$ & 83 & $\begin{array}{l}\text { The importance of responsible behaviour and } \\
\text { the reasons for making good life decisions } \\
\text { should be taught (T03) }\end{array}$ \\
\hline
\end{tabular}

Results also show that respondents feel a need to integrate scientific knowledge into everyday life. For example, while listing scientific concepts that must be taught, respondents also indicated that life skills that could help students apply knowledge must be taught. For example, one respondent (L010) indicated that students need to be taught how to make informed decisions. This view suggests that students need to be able to use knowledge (learnt in Biology) when making decisions. In support of this view, the respondent further argued for the development of reasoning skills related to application of knowledge during decisionmaking (L010). Overall, respondents imply that HIV/AIDS knowledge in Biology needs to be integrated with skills that will help students apply this knowledge in their daily lives.

While the findings generally indicate the need for HIV/AIDS education, some respondents appeared to feel otherwise. This is because some respondents felt that exposure to topics such as sex education somewhat stirs up the desire to experiment with sex among students. One student (L005) in particular argued that "students should not be taught how to use condoms 
because it increases the number of students who are sexually active and some don't use condoms properly." As a result, some blamed exposure to sex-related knowledge for the increased sex rate among students and consequently HIV infections. In fact, the students (4\%) who "never" use Biology knowledge in their decision-making (Table 1), also argued that knowledge is not enough to change students' unsafe behavioural practices. Instead, only life skills such as decision-making skills are important, as these do not only relate to HIV/AIDS but to other social challenges as well.

Previous research shows that some of the concepts listed in Table 2 are not presented in Biology (Mnguni, 2012). Consequently, with regards to content knowledge, findings suggest that there is a need to emphasize and clarify some scientific concepts taught in Biology. In addition, there are those concepts that are not currently taught but should be considered.

\section{Mode of presentation of HIV/AIDS-related concepts}

Respondents were also asked about the mode of presentation of HIV/AIDS knowledge that could improve students' understanding of HIV/AIDS concepts as well as the ability to apply that knowledge. It emerged that there are three categories of models that are recommended for presenting HIV/AIDS knowledge, namely human models, conceptual models and visual models. By human models, respondents indicated a need to use HIV/AIDS experts and people living with HIV to teach about the subject. By conceptual models respondents suggested the use of tools, such as textbooks, to present explicit and captivating information about HIV/AIDS. Respondents also recommended the use of visual models, which include pictures and videos that present information about HIV/AIDS. The study however did not investigate the impact of these models on students' understanding of HIV/AIDS, the use of scientific knowledge in everyday life or their behavioural practices. However findings revealed that 
Table 3. HIV/AIDS teaching strategies recommended by respondents. The recommended strategies were suggested by over $60 \%$ of respondents in the first round of data collection and by the proportion given in column 3 in the second round. Example quotes were taken from both rounds of data collection

\begin{tabular}{|c|c|c|c|}
\hline Category & $\begin{array}{l}\text { Recommended } \\
\text { strategy }\end{array}$ & $\begin{array}{l}\text { Frequency } \\
(\%)\end{array}$ & Quotes from respondents \\
\hline \multirow[t]{2}{*}{$\begin{array}{l}\text { Human } \\
\text { models }\end{array}$} & $\begin{array}{l}\text { Experts to teach } \\
\text { about HIV }\end{array}$ & 60 & $\begin{array}{l}\text { Medical doctors should be brought in to actually } \\
\text { show graphically the results of HIV/AIDS (L001) } \\
\text { Educate teachers so they can educate students. } \\
\text { Being an educator does not necessarily mean you } \\
\text { are well informed (E04) }\end{array}$ \\
\hline & $\begin{array}{l}\text { Exposure to } \\
\text { HIV-positive } \\
\text { individuals }\end{array}$ & 75 & $\begin{array}{l}\text { Students must be taken to institutions for people } \\
\text { with HIV and they must see for themselves the } \\
\text { dangers of the disease (T04) } \\
\text { We can have people with HIV talk about their } \\
\text { experiences (L206) }\end{array}$ \\
\hline \multirow[t]{2}{*}{$\begin{array}{l}\text { Conceptual } \\
\text { models }\end{array}$} & $\begin{array}{l}\text { Explicit } \\
\text { messages }\end{array}$ & 92 & $\begin{array}{l}\text { Don't sugar-coat HIV, tell it like it is, a very cruel } \\
\text { and unforgiving illness (E05) } \\
\text { Teachers must be open to talk about HIV/AIDS } \\
\text { when students ask (L232) } \\
\text { Knowledge should be practical so that students } \\
\text { can apply it (T02) }\end{array}$ \\
\hline & $\begin{array}{l}\text { Make it more } \\
\text { exciting }\end{array}$ & 50 & $\begin{array}{l}\text { Many children are bored by the topic of AIDS } \\
\text { (E03) }\end{array}$ \\
\hline $\begin{array}{l}\text { Visual } \\
\text { models }\end{array}$ & Use pictures & 65 & $\begin{array}{l}\text { More of those videos and gruesome pictures } \\
\text { showcasing the brutality of the disease (L020) } \\
\text { Students must see for themselves pictures of } \\
\text { HIV/AIDS patients (E01) } \\
\text { Give them true visuals so that they can see how } \\
\text { harmful the virus is (T09) }\end{array}$ \\
\hline
\end{tabular}

respondents believe HIV/AIDS education in the context of Biology should not only be based on one mode of presentation, particularly textbooks, which is the case in most impoverished schools in South Africa. Instead a combination of formats was recommended. Respondents (e.g. E03) felt that "some textbooks are not written in the context of those reading them and thus are irrelevant to local settings." As a result, it was suggested that "different modes be used to teach HIV/AIDS-related knowledge” (E03). Respondents in this regard argued that some Biology teachers are not well equipped for teaching HIV/AIDS-related concepts (Table 3). As a result, it was recommended that extra support from community members be provided. 
In this regard, respondents recommended that medical practitioners and researchers, community leaders and HIV-positive individuals be involved in HIV/AIDS education (Table $3)$.

Respondents also recommended the use of conceptual and visual models (Table 3). These models might include the use of written or spoken text, and motion (i.e. television) as well as still pictures to provide a detailed description of HIV/AIDS. Through these representations, respondents argued that a realistic and explicit reality of HIV/AIDS should be portrayed.

\section{Discussion}

The main objective of the current study was to identify strategies that can be used to enhance Biology students' understanding of HIV/AIDS and the usability of such knowledge in their daily lives. The critical aspect of the study was to gather data from students, teachers and HIV/AIDS experts, none of which have ever participated in curriculum development. This was important because the current Biology curriculum, designed by curriculum specialists, to some extent is not able to attend to some of the issues related to HIV/AIDS (Page et al., 2006).

A number of studies however have shown that knowledge does not seem to affect behaviours (Anderson and Beutel, 2007). However, reasons for this have not been fully explored. The current study shows that i) knowledge currently taught in Biology is not sufficient and ii) the mode of presenting such knowledge is unsatisfactory. The study shows that the majority of students report using Biology knowledge to make decisions related to HIV/AIDS. Therefore

scientific knowledge could be used to reduce risk behaviour which is associated with lack of knowledge. However, this also suggests that it is essential to ensure that HIV/AIDS 
knowledge presented in Biology is sufficient and scientifically correct to prevent misleading students. This is critical given that most students in rural South Africa, where HIV/AIDS prevalence is highest, only access scientific knowledge at school. Therefore, teachers need to ensure that selection of content as well as pedagogical practices do not lead to development of detrimental misconceptions.

Findings also suggest that there is a need to increase HIV/AIDS content knowledge taught in Biology. This in light of a number of concepts that are not presented in the current module yet deemed important by some students, teachers and HIV/AIDS experts. Therefore, the researchers argue that the relevance, applicability and scientific rigour should not be compromised by a superficial scope of HIV and AIDS content. Furthermore, the constructivist call for consideration of the needs and interests of the student (Thompson, 1995) should be heeded in order to foster the development of skills needed by the student to adopt safe behavioural practices.

Results also indicate a need to utilize various expertises for teaching about HIV/AIDS as well as modernizing instructional strategies. For example, the idea of using visualizations to teach concepts is in agreement with scholars in visual literacy (e.g. Mayer, 2001; Wastelinck et al., 2005) who suggest that students who use text alone do not show greater concept understanding than students who use diagrams and pictures to learn (e.g. Mayer, 2001). Furthermore, according to the theory of planned behaviour, knowledge (which follows content understanding) will influence beliefs and therefore behaviour. Therefore, the strategies for presenting HIV/AIDS knowledge recommended in the current study need to be explored to ensure that students have a improved and informed knowledge of HIV/AIDS that could influence behavioural practices. 
Also emerging from the data is the need to translate knowledge into practice, as some students fail to transfer classroom knowledge into everyday life. In this regard, findings suggest that there is a gap between the classroom experience and the everyday life experience. This view is in line with Anderson (2007) who argued that there is a gap between education (including research) and practice. Therefore, for Biology to be relevant, effective and transformative, students need to be taught actionable knowledge as well as the skills required to translate knowledge into practice (Hlebowitsh, 2006).

In conclusion, the authors argue that for the Biology curriculum to be transformative in the area of HIV/AIDS there is a need to broaden the scope of HIV/AIDS content and a revision of the instructional process in Biology.

\section{REFERENCES}

Ajzen, I. (1991). The theory of planned behaviour. Organizational Behaviour and Human Decision Processes, 50, 179-211.

Anderson, K. G., \& Beutel, A. M. (2007). HIV/AIDS prevention knowledge among youth in Cape Town, South Africa. Journal of Social Sciences, 3(3), 143-151.

Anderson, T. R. (2007). Bridging the educational research-teaching practice gap. Biochemistry and Molecular Biology Education, 53(6), 465-470.

Bertrand, J. T., O’Reilly, K., Denison, J., Anhang, R., \& Sweat, M. (2006). Systematic review of the effectiveness of mass communication programmes to change HIV/AIDS-related 
behaviours in developing countries. Health Education Research, Theory and Practice, 21(4), $567-597$.

Boath, E., Mucklow. J., \& Black, P. (1997). Consulting the oracle, a Delphi study to determine the content of a postgraduate distance learning course in therapeutics. British Journal of Clinical Pharmacology, 43, 643-647.

Clayton, R., Perera, R., \& Burge, S. (2006). Defining the dermatological content of the undergraduate medical curriculum, a modified Delphi study. British Journal of Dermatology, $155,137-144$.

Cohen, L. (1999). Philosophical perspectives in education. Retrieved from http//oregonstate.edu/instruct/ed416/PP3.html

Creswell, J. W. (2008). Educational research: planning, conducting and evaluating quantitative and qualitative research ( $3^{\text {rd }}$ ed.). Harlow: prentice Hall.

Department of Education (2003). National curriculum statement grades 10-12 (general), Biologys. Republic of South Africa, ISBN 1-919975-62-4.

Dewey, J. (1916) Democracy and education. New York: Free Press.

Dorrington, R. E., Johnson, L. F., Bradshaw, D., \& Daniel, T. (2006). The demographic impact of HIV/AIDS in South Africa. National and provincial indicators for 2006. Cape Town, Centre for Actuarial Research, South African Medical Research Council and Actuarial Society of South Africa.

Golafshani, N. (2003). Understanding reliability and validity in qualitative research. The Qualitative Report, 8(4), 597-607.

Hatcher, T., \& Colton, S. (2007). Using the internet to improve HRD research: The case of the web-based Delphi research technique to achieve content validity of an HRD-oriented measurement. Journal of European Industrial Training, 31(7), 570-587. 
Healy, M., \& Perry, C. (2000). Comprehensive criteria to judge validity and reliability of qualitative research within the realism paradigm. Qualitative Market Research-An International Journal, 3(3), 118-126.

Hlebowitsh, P. S. (2006). John Dewey and the idea of experimentalism. Education and Culture, 22(1), 73-76.

Hodson, D. (2004). Going Beyond STS: Towards a Curriculum for Socio-political Action. The Science Education Review, 3(1): 1 - 6.

Mayer, R. E. (2001). Meaningful learning from words and pictures, an educational psychology of multimedia. American Psychology Association, Newsletter for Educational Psychologists, 24(2), 1-3.

Page, J. A., Ebersohn, L., \& Rogan, J. (2006). The impact of an HIV/AIDS module on the knowledge and attitudes of grade 11 Biology students. African Journal of Research in SMT Education, 10(1), 103-114.

Thomas, D. R. (2003). A general inductive approach for qualitative data analysis. Retrieved from

http//74.125.155.132/scholar?q=cache,5KszkAirJJ8J,scholar.google.com/\&hl=en\&as_sdt=200 0

Thompson, P. W. (1995). Constructivism, cybernetics and information processing: Implications for technologies of research on learning. In L. P. Steffe \& J. Gale (Eds.), Constructivism in education. Hillsdale, New Jersey: Lawrence Erlbaum Associate Publishers. Wastelinck, K. D., Valcke, M., Craene, B. D., \& Kirschner, P. (2005). Multimedia learning in social sciences, limitations of external graphical representations. Computers in Human Behaviour, 21, 537-555. 


\section{Appendix 1}

1. How often do you use the knowledge learnt in school about HIV/AIDS to make decisions about your sexual life? Indicate your response by writing an " $X$ " on the correct box below.
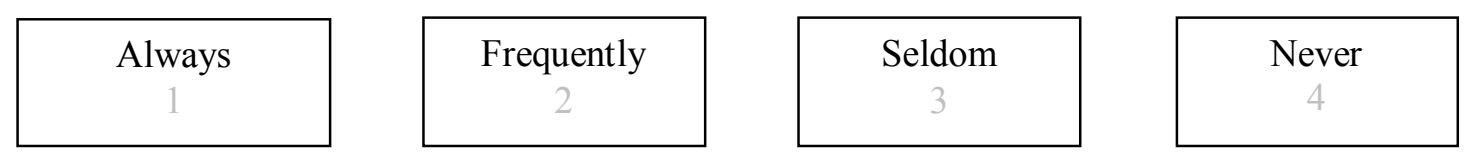

2. Indicate whether you strongly agree, agree, disagree or strongly disagree with the following statement by writing an " $X$ " on the correct box. Justify your response in the space provided.

2.1 Content knowledge related to the following themes should be taught in Grade 11 Biology in order for students to better understand HIV/AIDS:

a) Properties of HIV/AIDS

\begin{tabular}{|c|l|l|l|}
\hline Strongly agree & Agree & Disagree & Strongly disagree \\
\hline$\ldots \ldots \ldots \ldots \ldots \ldots \ldots \ldots \ldots \ldots \ldots \ldots \ldots \ldots \ldots \ldots \ldots \ldots \ldots \ldots \ldots \ldots \ldots \ldots \ldots \ldots \ldots \ldots \ldots \ldots \ldots \ldots \ldots \ldots \ldots \ldots \ldots \ldots \ldots \ldots \ldots \ldots$ \\
\hline
\end{tabular}

b) HIV modes of transmission

\begin{tabular}{|c|l|l|l|}
\hline Strongly agree & Agree & Disagree & Strongly disagree \\
\hline$\ldots \ldots \ldots \ldots \ldots \ldots \ldots \ldots \ldots \ldots \ldots \ldots \ldots \ldots \ldots \ldots \ldots \ldots \ldots \ldots \ldots \ldots \ldots \ldots \ldots \ldots \ldots \ldots \ldots \ldots \ldots \ldots \ldots \ldots \ldots \ldots \ldots \ldots \ldots \ldots$ \\
\hline
\end{tabular}

c) Effects of HIV infection on the body

\begin{tabular}{|c|c|c|c|}
\hline Strongly agree & Agree & Disagree & Strongly disagree \\
\hline
\end{tabular}

d) Human body's defence mechanisms against HIV

\begin{tabular}{|c|l|l|l|}
\hline Strongly agree & Agree & Disagree & Strongly disagree \\
\hline \multicolumn{1}{|c|}{$\ldots \ldots \ldots \ldots \ldots \ldots \ldots \ldots \ldots \ldots \ldots \ldots \ldots \ldots \ldots \ldots \ldots \ldots \ldots \ldots \ldots \ldots \ldots \ldots \ldots \ldots \ldots \ldots \ldots \ldots \ldots \ldots \ldots \ldots \ldots \ldots \ldots \ldots \ldots \ldots$} \\
\hline
\end{tabular}

e) Life skills

\begin{tabular}{|c|c|c|c|}
\hline Strongly agree & Agree & Disagree & Strongly disagree \\
\hline
\end{tabular}

2.2 Which other HIV/AIDS related content do you think should be taught in Biology?

3. Indicate whether you strongly agree, agree, disagree or strongly disagree with the following statement by writing an " $X$ " on the correct box. Justify your response in the space provided. 
3.1 The following strategies should be used to teach HIV/AIDS knowledge in order for students to have a better understanding of HIV/AIDS:

a) Medical experts should teach about HIV/AIDS in schools.

\begin{tabular}{|c|l|l|l|}
\hline Strongly agree & Agree & Disagree & Strongly disagree \\
\hline$\ldots \ldots \ldots \ldots \ldots \ldots \ldots \ldots \ldots \ldots \ldots \ldots \ldots \ldots \ldots \ldots \ldots \ldots \ldots \ldots \ldots \ldots \ldots \ldots \ldots \ldots \ldots \ldots \ldots \ldots \ldots \ldots \ldots \ldots \ldots \ldots \ldots \ldots \ldots \ldots \ldots \ldots$ \\
\hline
\end{tabular}

b) People living with HIV should teach about HIV/AIDS in schools.

\begin{tabular}{|c|l|l|l|}
\hline Strongly agree & Agree & Disagree & Strongly disagree \\
\hline$\ldots \ldots \ldots \ldots \ldots \ldots \ldots \ldots \ldots \ldots \ldots \ldots \ldots \ldots \ldots \ldots \ldots \ldots \ldots \ldots \ldots \ldots \ldots \ldots \ldots \ldots \ldots \ldots \ldots \ldots \ldots \ldots \ldots \ldots \ldots \ldots \ldots \ldots \ldots \ldots$ \\
\hline
\end{tabular}

c) Pictures of people with AIDS should be used to teach about HIV/AIDS.

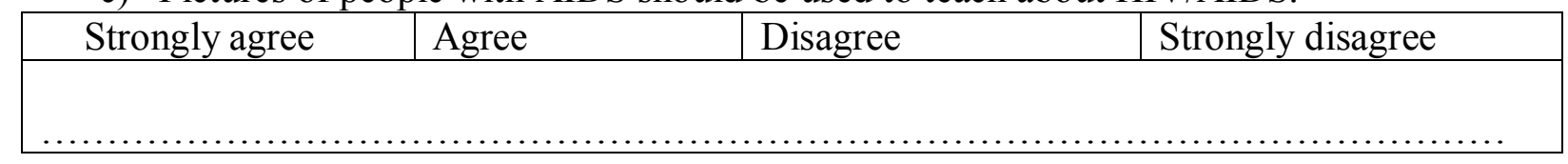

d) Visuals such as pictures of HIV should be shown to students.

\begin{tabular}{|c|c|c|c|}
\hline Strongly agree & Agree & Disagree & Strongly disagree \\
\hline
\end{tabular}

3.2 What other strategies do you recommend for teaching HIV/AIDS knowledge?

\section{What other recommendations do you have for the teaching of HIV/AIDS knowledge in Biology?}

